Article

\title{
Application of Synthetic Layered Sodium Silicate Magadiite Nanosheets for Environmental Remediation of Methylene Blue Dye in Water
}

\author{
Mohamed Mokhtar 1,2 (iD) \\ 1 Chemistry Department, Faculty of Science, King Abdulaziz University, P.O. Box 80203, Jeddah 21589, \\ Saudi Arabia; mmokhtar2000@yahoo.com or mmoustafa@kau.edu.sa; Tel.: +966-26-194-983; \\ Fax: +966-26-952-292 \\ 2 Physical Chemistry Department, National Research Centre, El Buhouth St., Dokki, Cairo 12622, Egypt
}

Received: 13 May 2017; Accepted: 3 July 2017; Published: 6 July 2017

\begin{abstract}
The removal of methylene blue (MB) dye from water was investigated using synthetic nano-clay magadiite (SNCM). SNCM was synthesized by a hydrothermal treatment under autogenous pressure. A rosette-shaped single mesoporous magadiite phase with $16.63 \mathrm{~nm}$ average crystallite size and $33 \mathrm{~m}^{2} \cdot \mathrm{g}^{-1}$ Braunauer-Emmet-Teller (BET)-surface area was recorded. The adsorption results indicated the pronounced affinity of the SNCM to the MB dye molecules, which reached an adsorption uptake of $20.0 \mathrm{mg} \mathrm{MB}$ dye/g of SNCM. The elimination of MB dye by the SNCM was kinetically and thermodynamically considered; a pseudo-second-order kinetic model was attained, and its spontaneous, chemical, and endothermic nature was verified. SNCM was shown to be robust without a detectable reduction in the adsorption capacity after up to four times re-use.
\end{abstract}

Keywords: adsorption; magadiite; cationic clay; methylene blue; remediation

\section{Introduction}

Water pollution is one of the most serious problems that threatens the life of humankind and other living organisms on Earth. This is mainly due to the extensive industrialization of all aspects of our lives, and the spreading of all classes of pollutants in the ecosystem. Organic pollutants are one of the most dangerous classes of pollutant, and greatly affect human health and cause many diseases due to their persistent nature in biological systems. This class of pollutants is introduced to the aquatic environment from the discharge of many industries, such as textiles, pharmaceuticals, packaging, tanning, etc. Currently, increasingly severe limits on the extent of organic pollutants have been established. There are different methods used to treat industrial waste water containing organic dyes: photo-degradation [1], reverse osmosis [2], biological treatment [3], and oxidative degradation [4]. However, most of these methods generally suffer from disadvantages such as low efficiency, extraordinary cost, the emergence of ancillary contaminants, revival problems, and long retention periods. One of the most promising and efficient methods of wastewater treatment is adsorption, which is characterized with simple utilization, low cost, and the facility to revive both adsorbent and pollutants [5,6]. It is well known that activated carbon is the most frequently used solid adsorbent for the removal of different organic and inorganic pollutants from different aquatic environments [7-10]. Nowadays, research scientists world-wide are looking for innovative classes of adsorbents characterized by high adsorption efficiency, as well as strong affinity towards certain environmental pollutants such as organic dyes. Synthetic nanoclay minerals are a new class of nanomaterial characterized by unique features, such as their intercalated anionic layered structure, which could be substituted by another cation in the interlayer gallery; purity of their structure; and their well-designed composition, which enable them to be used in different applications, such as catalysis [11,12], nanocomposite reinforcement [13-15], and antibacterial 
agents [16]. Moreover, different clays have been used for environmental remediation for the removal of heavy metals [17,18], the antimicrobial peptides nisin and pediocin [19], herbicides [20], vitamin B1 [21], and different organic dyes [22-26].

However, the application of synthetic nano-clay magadiite (SNCM) for the elimination and remediation of different contaminants from the water environment is rare in the literature [27-29]; extra effort is desired to discover the adsorption capabilities of synthetic nano-clay magadiite as an effective adsorbent for the elimination of organic dye as a specimen of organic contaminants-a main class of ecological contaminants that are persistent in the environment and cause antagonistic possessions on both fauna and flora.

Na-magadiite $\left(\mathrm{Na}_{2} \mathrm{Si}_{14} \mathrm{O}_{29} \cdot n \mathrm{H}_{2} \mathrm{O}\right)$ is one of the most significant aluminum-free layered silicates, with an unknown exact crystal structure. However, three probable structures have been anticipated [30]. Furthermore, the layered appeal and the swelling behavior of Na-magadiite are well designated in the literature [31-34]. It is well recognized that the layers of Na-magadiite can be prolonged by suitable treatment by intercalation of guest molecules among the sheets of Na-magadiite, which opens the gate for possible adsorption affinity.

In the present work, synthetic nanoclay Na-magadiite (SNCM) was synthesized and characterized with dissimilar methods: by scanning electron microscope (SEM), surface area analyzer (SAA), and $X$-ray diffraction (XRD). It was then used for the elimination of methylene blue dye (MB) —as an example organic contaminant-from a model solution and a wastewater sample. The influence of the different operational parameters affecting the removal process was studied and optimized. The adsorption of the MB dye from the model solution by SNCM was revealed kinetically using altered kinetic models and thermodynamics to gain a sympathetic understanding of the adsorption process.

\section{Experimental}

\subsection{Materials}

All chemicals were of analytical grade and were obtained from Sigma-Aldrich (Aldrich, Dorset, UK). The experiments were performed using de-ionized water with a resistivity that did not exceed 18.2 $\mathrm{M} \Omega \cdot \mathrm{cm}$ and which was obtained with a Millipore Milli-Q system (Billerica, MA, USA). A stock solution $\left(100 \mathrm{mg} \cdot \mathrm{L}^{-1}\right)$ was prepared by dissolving a known quantity of MB dye in de-ionized water. The stock solution was further diluted to the desired concentration for other experiments.

\subsection{Synthesis of SNCM}

SNCM was synthesized using hydrothermal treatment under autogenous pressure at $150{ }^{\circ} \mathrm{C}$ of a viscous weak alkaline and $\mathrm{SiO}_{2}$-rich area of the ternary system $\mathrm{Na}_{2} \mathrm{O} / \mathrm{SiO}_{2} / \mathrm{H}_{2} \mathrm{O}$ [35]. The molar gel composition was $5 \mathrm{SiO}_{2}: \mathrm{Na}_{2} \mathrm{O}: 75 \mathrm{H}_{2} \mathrm{O}$. From the chemical and thermogravimetric analysis (TGA), it was found that the chemical composition of the synthesized Na-magadiite was $13.8 \mathrm{SiO}_{2}: \mathrm{Na}_{2} \mathrm{O}: 9.8 \mathrm{H}_{2} \mathrm{O}$.

\subsection{Characterization}

The XRD diffraction pattern was obtained using an X'pert Pro diffractometer from Phillips Analytical (Almelo, The Netherlands). CuK $\alpha$ radiation $(\lambda=1.54056 \AA)$ was used. The sample was measured in the sample holder with a small exposure area. The diffraction pattern of the sample was measured by using the following program: $2 \theta$ angle from $2^{\circ}$ to $50^{\circ}$ with a step of $0.02^{\circ}$ and a duration of $3 \mathrm{~s}$ per step. Morphology of the samples was determined by using Carl Zeiss Gemini ULTRA 55 SEM equipment at a $3 \mathrm{kV}$ voltage and with an SE 2 detector (MST AG, Germany). Nitrogen-sorption measurements were taken by first carrying out a pre-treatment of the samples. During pre-treatment, the samples were heated with a $1{ }^{\circ} \mathrm{C}$ per minute rate to $250{ }^{\circ} \mathrm{C}$ under high vacuum, and kept at these conditions for $12 \mathrm{~h}$. Analysis measurement was performed at a temperature of $-176{ }^{\circ} \mathrm{C}$ in liquid nitrogen with Quadrasorb SI equipment (Quantachrome, Boynton Beach, FL, USA). 


\subsection{Adsorption Studies}

The adsorption experiments were carried out in batch mode by mixing a specific amount of SNCM and $10 \mathrm{~mL}$ of MB dye solution in a stoppered conical flask under constant shaking (120 rpm) in a thermostat shaker. The effects of contact time, SNCM dosage, $\mathrm{pH}$, ionic strength, and temperature of the MB dye solutions were investigated. For determination of the equilibrium time of adsorption, the experiments were carried out in specific time intervals using $0.25 \mathrm{mg}$ of the SNCM and $5 \mathrm{mg} / \mathrm{L}$ MB dye solution. For the effect of SNCM dosage experiments, 1-70 $\mathrm{mg}$ of SNCM and $10 \mathrm{~mL}$ of $5 \mathrm{mg} / \mathrm{L}$ MB dye solution were used at $20^{\circ} \mathrm{C}$ and a contact time of $60 \mathrm{~min}$. For the effect of solution $\mathrm{pH}$, $10 \mathrm{mg}$ of SNCM and $10 \mathrm{~mL}$ of $5 \mathrm{mg} / \mathrm{L} \mathrm{MB}$ dye solution were used at $20^{\circ} \mathrm{C}$ and a contact time of $60 \mathrm{~min}$. For the effect of ionic strength, $10 \mathrm{mg}$ of SNCM and $10 \mathrm{~mL}$ of $5 \mathrm{mg} / \mathrm{L} \mathrm{MB}$ dye solution were used at $20^{\circ} \mathrm{C}$ and a contact time of $60 \mathrm{~min}$. The temperature effect was investigated kinetically at three different temperatures: 20,35 , and $50{ }^{\circ} \mathrm{C}$. After the completion of the adsorption experiment, the solution was immediately filtered to collect the supernatant, and the residual MB dye concentration in the supernatant was measured using a UV-VIS instrument at $664 \mathrm{~nm}$. The removal efficiency was expressed as the percentage of MB dye removed, and the uptakes of SNCM $\left(q_{e}, \mathrm{mg} / \mathrm{g}\right)$ were calculated by Equations (1) and (2), respectively:

$$
\begin{gathered}
\% M B \text { dye removed }=\frac{\left(C_{0}-C_{e}\right)}{C_{0}} \times 100 \\
q_{e}=\frac{\left(C_{0}-C_{e}\right) \times V}{m}
\end{gathered}
$$

where $C_{0}$ and $C_{e}(\mathrm{mg} / \mathrm{L})$ are the initial and equilibrium concentrations of the $\mathrm{MB}$ dye in solution, respectively; $V(\mathrm{~L})$ is the volume of the MB dye solution; and $\mathrm{m}(\mathrm{g})$ is the SNCM dosage.

\section{Results and Discussion}

\subsection{Characterization of the SNCM}

The X-ray diffraction pattern of the as-synthesized dried sample showed the characteristic peaks of magadiite at $5.6^{\circ}, 11.3^{\circ}$, and $17.11^{\circ} 2 \theta$ corresponding to the (001), (002), and (003) diffraction planes, respectively [36]. The crystalline nature of the magadiite phase layer was indicated by the peaks found between $23^{\circ}$ and $30^{\circ} 2 \theta$. In addition, a basal spacing of $1.54 \mathrm{~nm}$ corresponding to the $d_{001}$ reflection was detected, as shown in Figure 1 [37]. The average crystallite size was $16.63 \mathrm{~nm}$, and the lattice strain was 0.0416 as deduced from Scherrer equation [38]. The small crystallite size of SNCM indicates the presence of the anionic sheets as nano-sheets.

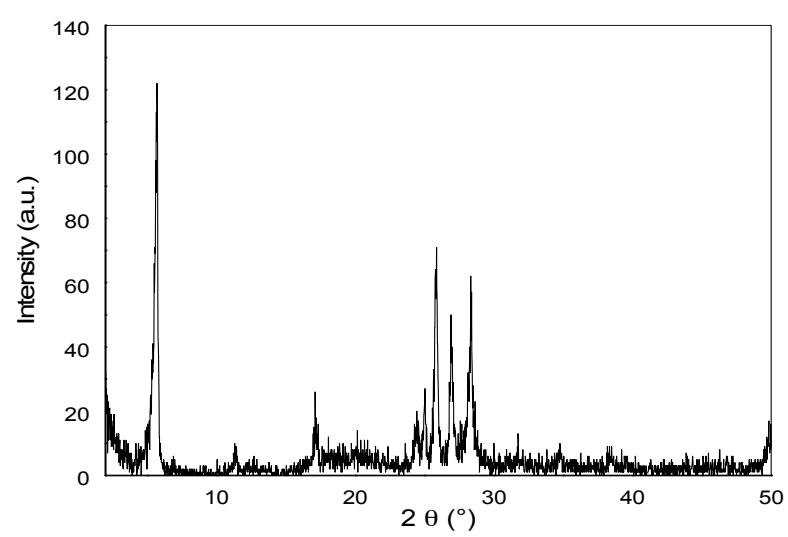

Figure 1. X-ray diffraction pattern of the as-synthesized layered sodium silicate magadiite. 
SEM image (Figure 2) of SNCM showed well-crystallized rosette-shaped Na-magadiite particles (SEM), with a diameter for the "flower" and "petals" of about 5-7 $\mu \mathrm{m}$. The single magadiite crystalline phase was obtained as a result of the controlled hydrothermal reaction temperature at $150{ }^{\circ} \mathrm{C}$. It was reported in the literature that the effect of the temperature is much more important than the reaction time and concentration in order to synthesize single magadiite phase, and the reaction temperature must be below $170{ }^{\circ} \mathrm{C}$ [39].

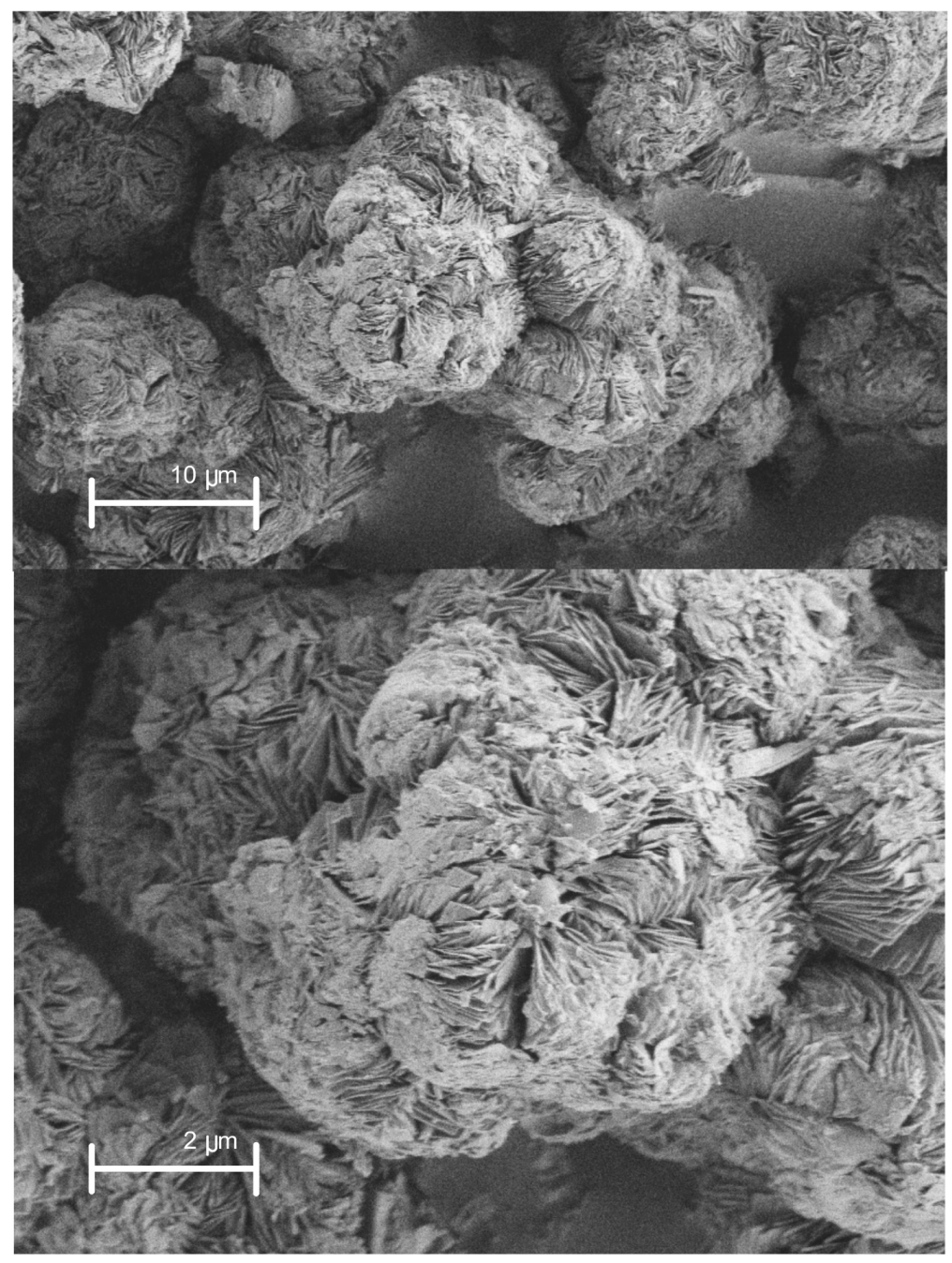

Figure 2. SEM image of as-synthesized layered sodium silicate magadiite.

The $\mathrm{N}_{2}$ sorption isotherm and Barrett-Joyner-Halenda $(\mathrm{BJH})$ pore size distribution shown in Figure 3 were obtained for SNCM sample. The preliminary monolayer-multilayer adsorption on the mesopore walls receives a similar track to the type II isotherm, and is shadowed by pore condensation with $\mathrm{H}_{3}$ hysteresis according to IUPAC classification in 1985 [40]. This loop shape is due to the non-rigid aggregates of Na-magadiite plate-like particles and macropores which are not entirely occupied with pore condensate [41]. SNCM has a BET surface area of $39 \mathrm{~m}^{2} \cdot \mathrm{g}^{-1}$ and a total pore volume of $0.3 \mathrm{~cm}^{3} \cdot \mathrm{g}^{-1}$. The small surface area of Na-magadiite is identical to the alkaline magadiite reported elsewhere [42]. Surface areas of magadiite could not be entirely attributed to the exterior surface due to the layered structure, in which the nitrogen has contact. Although the low BET surface area of SNCM could negatively affect the adsorption capacity towards the organic dye, the intercalation ability between the anionic sheets of magadiite could compensate for this plausible effect. The multi-modal pore size structure is shown in the inset of Figure 3. The average pore size of SNCM is ca. $28 \AA$. 


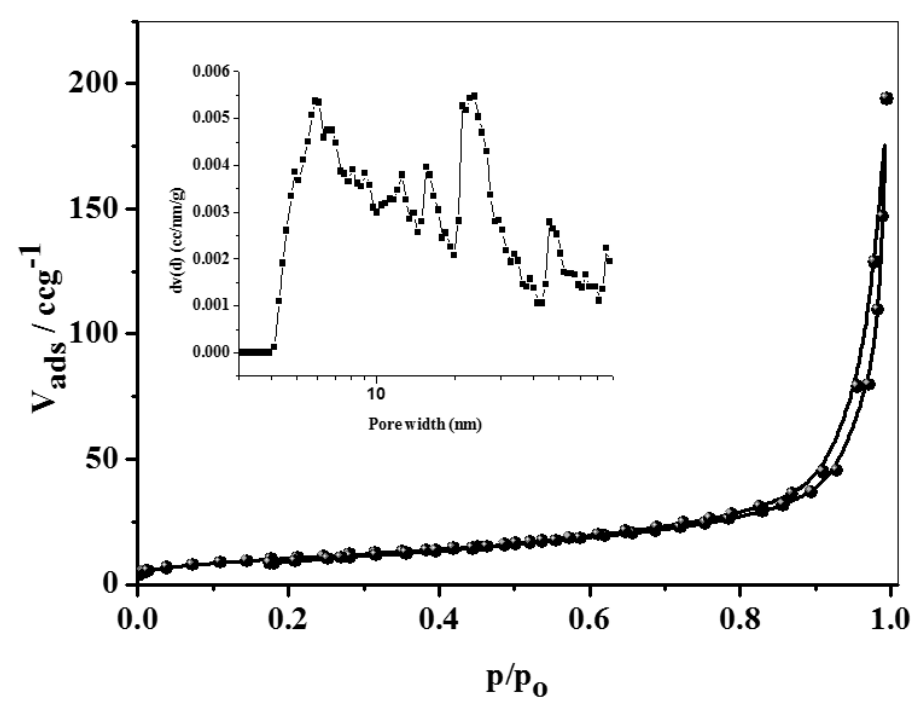

Figure 3. The $\mathrm{N}_{2}$ sorption isotherm and pore size distribution curve for SNCM.

\subsection{Effect of Operational Parameters}

Environmental and operational parameters greatly affect the removal and adsorption of pollutants from water using any solid adsorbent. Therefore, the study of adsorption contact time, SNCM dosage, solution $\mathrm{pH}$, and ionic strength are of great importance. The effect of time on the adsorption of MB dye from an aqueous solution by SNCM was studied to explore the time required to reach equilibrium, and the results are presented in Figure 4. As shown in Figure 4, the percentage of MB dye removed from the solution reached $46.3 \%$ within $1 \mathrm{~min}$ and significantly increased to $90.3 \%$ after $25 \mathrm{~min}$, and to $91.0 \%$ within $30 \mathrm{~min}$ A further increase in the contact time did not significantly alter the percentage of MB dye removed, which reached $94.0 \%$ after $60 \mathrm{~min}$, and consequently, a contact time of $30 \mathrm{~min}$ was selected for further studies. Figure 5 shows the effect of the SNCM dosage on the removal of MB dye from aqueous solution. It is clear that most of the MB dye was removed from the solution using $5 \mathrm{mg}$ of the SNCM; $97.5 \%$ of the MB dye was removed, and this removal percentage did not change with a further increase in the SNCM dosage. This means that $5 \mathrm{mg}$ of the SNCM was adequate to remove the $\mathrm{MB}$ dye completely from the solution, and this level was selected for further studies.

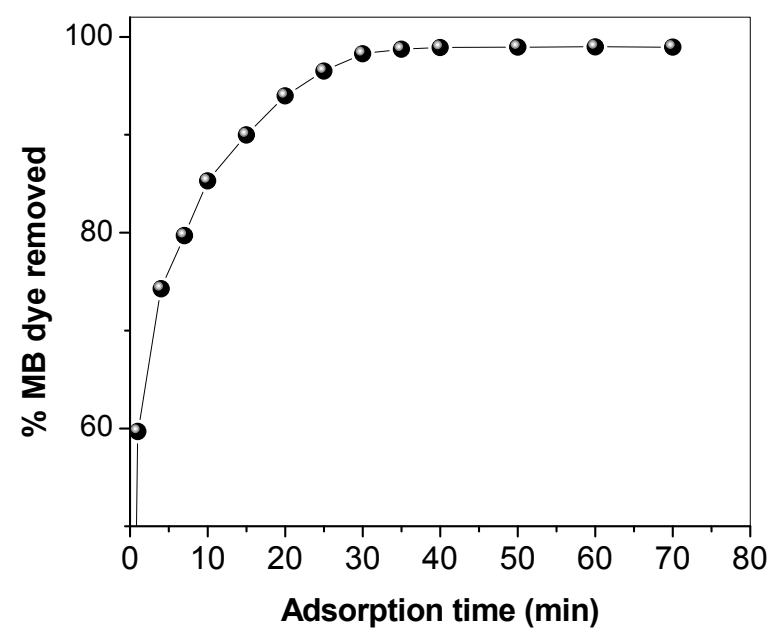

Figure 4. Effect of adsorption time on the percentage of methylene blue dye (MB) removed from an aqueous solution by synthetic nano-clay magadiite (SNCM). 


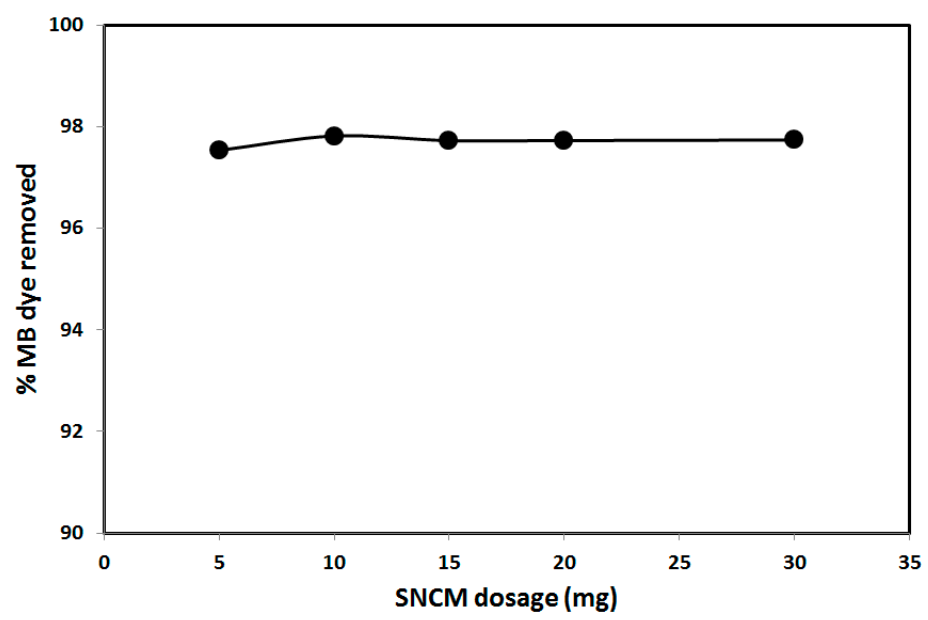

Figure 5. Effect of the SNCM dosage on the removal of methylene blue dye from an aqueous solution.

The effect of solution $\mathrm{pH}$ on the removal of MB dye by SNCM was investigated due to its significant effect on the adsorption process, and the results are presented in Figure 6. The results show that increasing the solution $\mathrm{pH}$ was accompanied by a slight enhancement in the percentage of MB dye removal: $95.1 \%, 96.4 \%$, and $98.6 \%$ at $\mathrm{pH}$ values of 2,4 , and 6 , respectively. This indicated the insignificant competition between the hydronium ions $\left(\mathrm{H}_{3} \mathrm{O}^{+}\right)$and the $\mathrm{MB}$ molecules for the adsorption on the SNCM surface at low $\mathrm{pH}$ values. A further increase in the solution $\mathrm{pH}$ to 8 was associated with a slight decrease in the percentage of $\mathrm{MB}$ dye removed, where it decreased to $93.8 \%$, which significantly decreased to $62.4 \%$ upon increasing the solution $\mathrm{pH}$ to 10 . This decrease in the adsorption capacity upon elevating the $\mathrm{pH}$ values could be attributed to competition between the $\mathrm{MB}$ dye molecules and the hydroxyl ions present at these $\mathrm{pH}$ values, as the $\mathrm{MB}$ dye molecules are insensitive to the $\mathrm{pH}$ change [43]. Additionally, the point of zero charge for the SNCM was measured and was 5.1, indicating that the SNCM surface is negatively charged at $\mathrm{pH}$ values higher than 5.1, which accordingly creates electrostatic repulsion with the negatively-charged $\mathrm{MB}$ (with a $p \mathrm{~K}_{\mathrm{a}}$ value of 3.14), which agrees well with previous results $[29,44]$. The effect of ionic strength on the removal of organic pollutants such as MB dye from water by solid adsorbents such as SNCM is significant, because it sheds light on the nature of the interactions between the MB dye molecule and the SNCM surface, and explains if it is electrostatically attractive or repulsive [28].

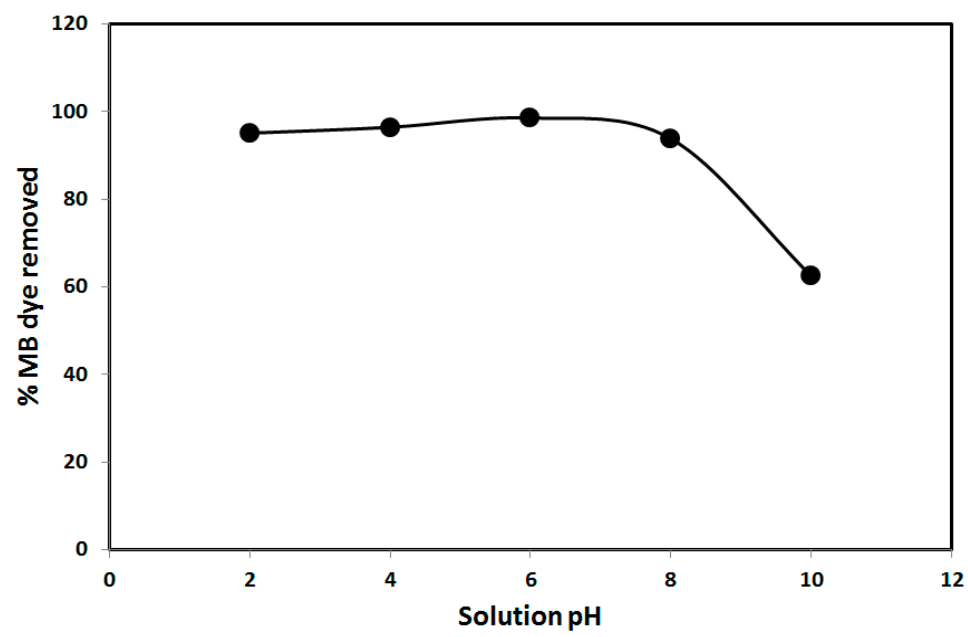

Figure 6. Effect of solution $\mathrm{pH}$ on the percentage of methylene blue dye removed from an aqueous solution by SNCM. 
The effect of the ionic strength on the removal of MB dye from water using SNCM was studied using different concentrations of $\mathrm{KNO}_{3}$, and the results are presented in Figure 7. It is clear that the percentage of $\mathrm{MB}$ dye removed was insignificantly affected by an increase in $\mathrm{KNO}_{3}$ from 0.005 to 0.01 M: $95.0 \%$ and $94.2 \%$, respectively. A further increase in $\mathrm{KNO}_{3}$ concentration to 0.05 and $0.1 \mathrm{M}$ caused the decrease in the percentage of MB dye removed to $88.6 \%$ and $73.2 \%$, respectively. This may be due to the hindering effect of the high concentration of $\mathrm{K}^{+}$and $\mathrm{NO}_{3}{ }^{-}$ions, indicating the electrostatic nature of the MB dye adsorption by the SNCM surface.

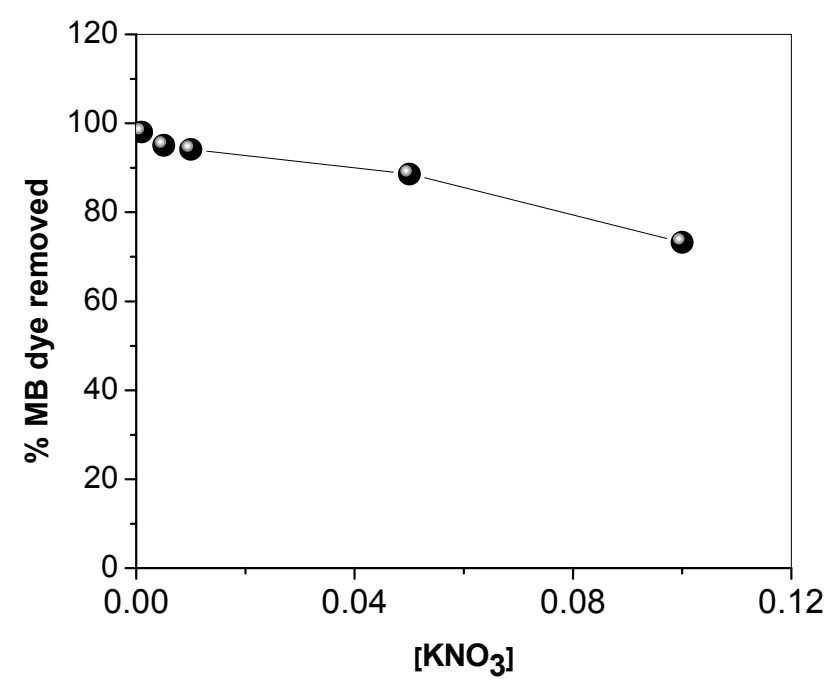

Figure 7. Effect of solution ionic strength on the percentage of methylene blue dye removed from an aqueous solution by SNCM.

\subsection{Kinetics and Thermodynamics Studies}

The variation of the amount of MB dye adsorbed by SNCM as a function of the adsorption time was studied at three different temperatures-293, 308 and $323 \mathrm{~K}$ - and the experimental results are shown in Figure 8. It is clear from the figure that the amount of MB dye removed from solution by SNCM reached equilibrium within $30 \mathrm{~min}: 18.5,19.6$, and $19.9 \mathrm{mg} \mathrm{MB} / \mathrm{g} \mathrm{SNCM}$ at 20, 35, and $50^{\circ} \mathrm{C}$, respectively, and no significant improvement in the amount of $\mathrm{MB}$ dye removed was observed with a further increase in time. Additionally, it was clear that the adsorption was endothermic in nature, as the amount of $\mathrm{MB}$ dye removed was enhanced with increasing solution temperature: 18.8, 19.8, and $20.0 \mathrm{mg} \mathrm{MB} / \mathrm{g} \mathrm{SNCM}$ at 20, 35 and $50{ }^{\circ} \mathrm{C}$ after $60 \mathrm{~min}$, respectively.

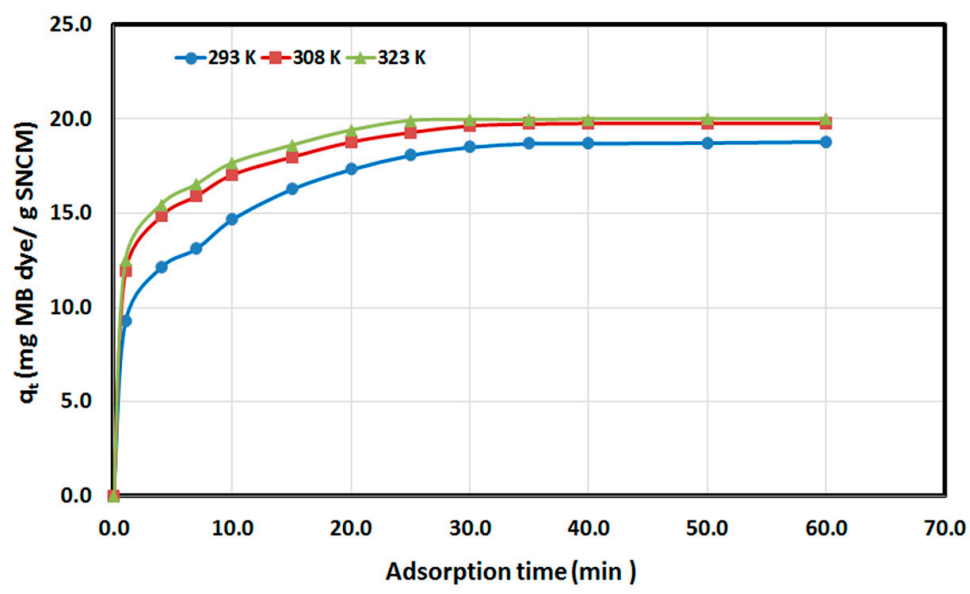

Figure 8. Variation of the amount MB dye adsorbed per unit mass of SNCM $\left(q_{t}\right)$ with time. 
The experimental results of the effect of contact time on the removal of MB dye by SNCM were used to study the adsorption kinetics using the most used kinetic models-namely, the pseudo-first-order kinetic model and the pseudo-second-order kinetic model, as presented in Equations (3) and (4), respectively:

$$
\begin{gathered}
\ln \left(q_{e}-q_{t}\right)=\ln q_{e}-k_{1} t \\
\frac{t}{q_{t}}=\frac{1}{k_{2} q_{e}^{2}}+\frac{t}{q_{e}}
\end{gathered}
$$

where $q_{e}$ and $q_{t}$ are the values of the amount MB dye adsorbed per unit mass of SNCM at equilibrium and at any time $t$, respectively; $k_{1}\left(\mathrm{~min}^{-1}\right), k_{2}(\mathrm{~g} /(\mathrm{mg} \cdot \mathrm{min}))$ are the pseudo-first-order adsorption rate coefficient, and pseudo-second-order rate coefficient, respectively. Applying the pseudo-first-order kinetic model (Equation (3)) to the experimental results (Figure 9), the plot of $\ln \left(q_{e}-q_{t}\right)$ vs. $t$ for MB dye at different temperatures did not converge well and did not give straight lines (as is clear from Figure 9), with unacceptable regression coefficients. Additionally, the estimated values of the amount adsorbed at equilibrium $\left(\boldsymbol{q}_{e, \text { calc }}\right)$ were far from the experimental values $\left(\boldsymbol{q}_{\boldsymbol{e}, \text { exp }}\right)$. This indicated that pseudo-first-order kinetic model is not appropriate for the description of MB dye removal by SNCM from water. Applying the pseudo-second-order kinetic model (Equation 4) to the experimental data, the plot of $t / q_{t}$ vs. $t$ converged well, with straight lines and an excellent regression coefficient higher than 0.99, as presented in Figure 10. In addition, there was an excellent correlation between the calculated amount of MB adsorbed by the $\operatorname{SNCM}\left(q_{e, \text { calc }}\right)$ and the experimental values $\left(q_{e, \text { exp }}\right)$. These findings confirmed the suitability of the pseudo-second-order kinetic model for describing the removal of MB dye from the model solution by SNCM.

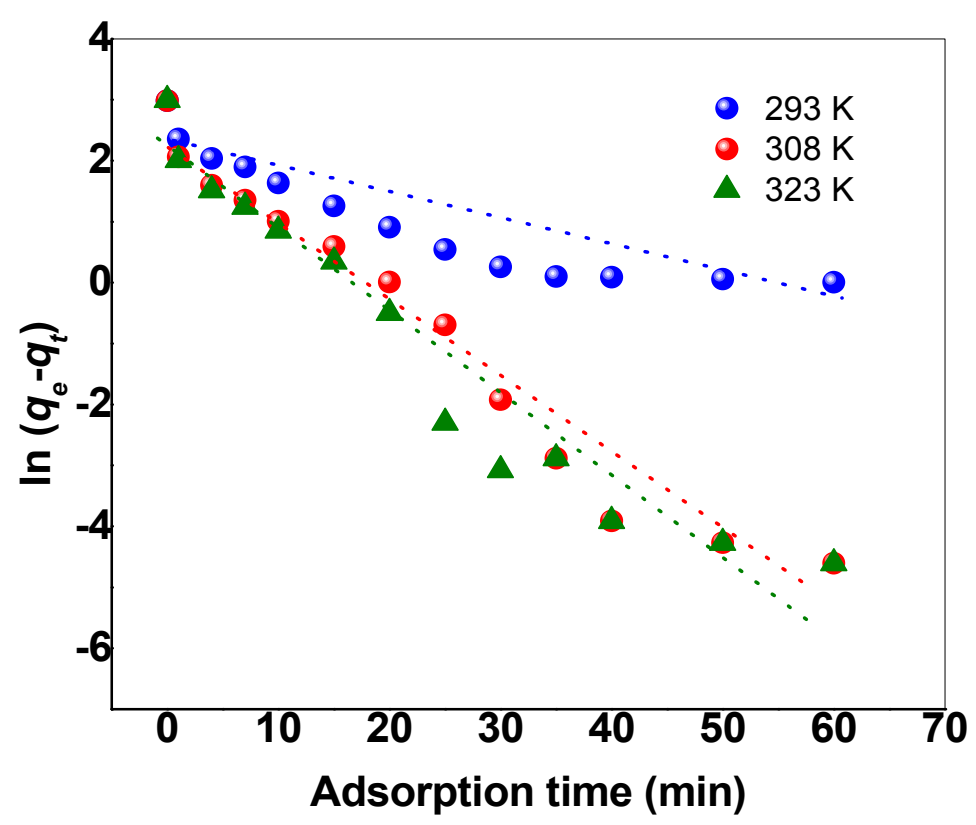

Figure 9. The application of the pseudo-first-order kinetic model for the MB dye removed from an aqueous solution by SNCM. 


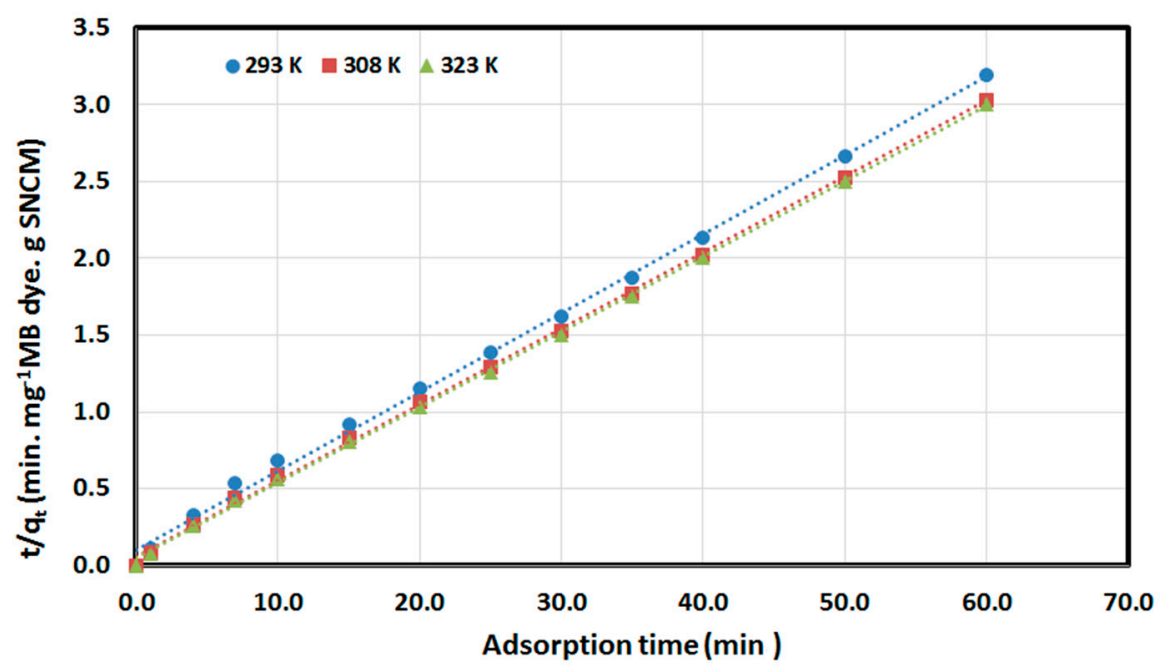

Figure 10. The application of the pseudo-second-order kinetic model for the MB dye removed from an aqueous solution by SNCM.

There are many previous studies that also showed the suitability of the pseudo-second-order kinetic model for the description of $\mathrm{MB}$ dye from water by the different solid adsorbents, such as $\mathrm{Fe}_{3} \mathrm{O}_{4}$-graphene@mesoporous $\mathrm{SiO}_{2}$ nanocomposites [45], zeolite synthesized from electrolytic manganese residue [46], zinc oxide nanorods loaded on activated carbon [47], activated carbon [48], poly(sodium p-styrene sulfonate)/poly(methyl methacrylate) particles [49], and many other adsorbents. The thermodynamic parameters include the enthalpy change $(\Delta H)$, free energy change $(\Delta G)$, and entropy change $(\Delta S)$, and were calculated to evaluate the thermodynamic feasibility and the spontaneous nature of the MB dye removal by SNCM according to the following equations:

$$
\begin{gathered}
D=\frac{q_{e}}{C_{e}} \\
\ln D=\left(\frac{\Delta S}{R}\right)-\frac{\Delta H}{R} \times \frac{1}{T} \\
\Delta G=\Delta H-T \Delta S
\end{gathered}
$$

where $D$ is the distribution coefficient; $R$ is the gas constant $\left(8.314 \mathrm{~J} \cdot \mathrm{mol}^{-1} \cdot \mathrm{K}^{-1}\right)$; and $T$ is the temperature (K). The values of $\Delta H$ and $\Delta S$ are determined from the slope and the intercept of the plots of $\ln D$ versus $1 / T$, which is associated with a good correlation coefficient; $R^{2}$ equal 0.961 , as is shown in Figure 11. The removal of MB dye using SNCM from water associated with $\Delta H$ value of $+144.0 \mathrm{~kJ} / \mathrm{mol}$, indicating the adsorption process was endothermic in nature. This finding confirmed the above-mentioned result that the adsorption is fast and obeys the pseudo-second-order kinetic model. The $\Delta S$ value of $+523 \mathrm{~J} / \mathrm{mol} \cdot \mathrm{K}$ indicates the increase in the degree of disorder upon the adsorption of the MB dye molecules by the SNCM. The $\Delta G$ value was calculated based on Equation (7) at $20{ }^{\circ} \mathrm{C}$, and the value was found to be negative $(-9.18 \mathrm{~kJ} / \mathrm{mol})$, indicating that the process was spontaneous, and this value became more negative by raising the solution temperature: $-16.9 \mathrm{~kJ} / \mathrm{mol}$ and $-24.6 \mathrm{~kJ} / \mathrm{mol}$ at $35^{\circ} \mathrm{C}$ and $50{ }^{\circ} \mathrm{C}$, respectively. It could be concluded here that the more negative the $\Delta G$ value, the more spontaneous the removal, which was accompanied by higher values of MB dye uptake by the SNCM. Additionally, the negative values of $\Delta G$, the positive value of $\Delta H$, and the positive value of $\triangle S$ indicated that the removal of MB dye by SNCM is an entropy-driven process. According to the kinetics and thermodynamics study, the MB dye removal by SNCM could be described by the pseudo-second-order kinetic model, and was spontaneously endothermic and chemical in nature. 


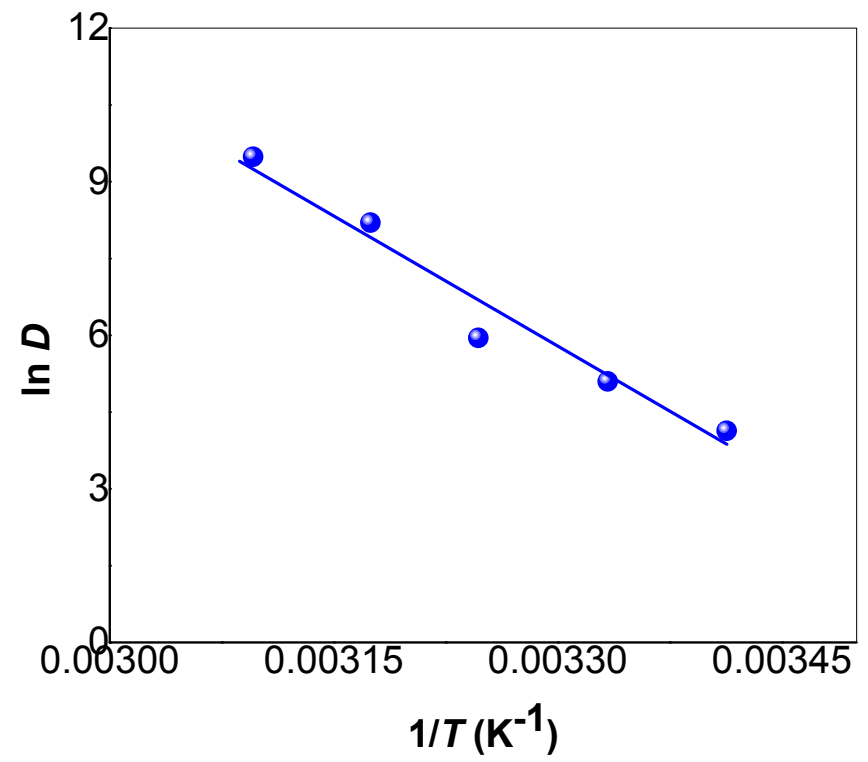

Figure 11. Plot of $\ln D$ vs. $1 / T$ for the $\mathrm{MB}$ dye removed from an aqueous solution by SNCM.

According to the above results, the adsorption capacity of MB by SNCM at ambient temperature is $18.8 \mathrm{~g} \mathrm{MB} / \mathrm{g}$ within $30 \mathrm{~min}$. In comparison with other adsorbents, SNCM could be considered as a potential and promising adsorbent for the removal of organic dyes, such as MB from water. This adsorption capacity is much higher and better compared with spent rice biomass: $8.13 \mathrm{mg} \mathrm{MB/g}$ [50]; activated carbon prepared from rice husk: $9.73 \mathrm{mg} \mathrm{MB} / \mathrm{g}$ [51]; natural Jordanian Tripoli: $16.6 \mathrm{mg} \mathrm{MB} / \mathrm{g}$ [52]; and lower compared with manganese oxide nanocorals: $41.26 \mathrm{mg} \mathrm{MB} / \mathrm{g}$ [46]; and surface hydroxyl group-enriched $\mathrm{TiO}_{2}$ nanotubes: $57.14 \mathrm{mg} / \mathrm{g}$ [53]. In general, based on the above results, it could be stated that SNCM is a promising and potentially competitive adsorbent for the removal of organic dyes such as MB from solution.

\section{Recycle Study}

The recycle and reuse of the SNCM was studied. The desorption process was performed by soaking and washing the SNCM sample in acetone, then drying and reusing it for the removal of MB from solution. The percentage of MB removed was $98.1 \%$ using $5 \mathrm{mg}$ of SNCM, and this value did not change significantly after four cycles of reuse. This showed the great ability to recycle and reuse SNCM many times without losing adsorption efficiency.

\section{Conclusions}

The removal of the organic dye methylene MB from water was studied using SNCM. Firstly, SNCM was synthesized by hydrothermal treatment under autogenous pressure and then characterized using different techniques in order to explore its physical and morphological structure. The XRD results showed the characteristic peaks of magadiite with average crystallite size $16.63 \mathrm{~nm}$, and the SEM images showed well-crystallized rosette-shaped $\mathrm{Na}$-magadiite particles with diameters for "flower" and "petal" of about $5-7 \mu \mathrm{m}$, and BET-surface area $33 \mathrm{~m}^{2} \cdot \mathrm{g}^{-1}$. The effects of different operational and environmental parameters, such as removal time, $\mathrm{SNCM}$ dosage, contact time, $\mathrm{pH}$, and ionic strength of the solution, on the removal of $\mathrm{MB}$ dye were explored. The adsorption results showed the great affinity of the SNCM to the MB dye molecules, which reached an adsorption uptake of $20.0 \mathrm{mg} \mathrm{MB}$ dye/g of SNCM. The removal of MB dye by SNCM was studied kinetically and thermodynamically, was found to follow the pseudo-second-order kinetic model, and was spontaneous and endothermic in nature. Finally, SNCM showed that it can be considered as a promising adsorbent for the removal of MB dye from an aqueous solution. 
Acknowledgments: This project was funded by the Deanship of Scientific Research (DSR) at King Abdulaziz University, Jeddah, under grant No. (130-777-D1435). The authors, therefore, acknowledge with thanks, DSR for technical and financial support.

Conflicts of Interest: The author declares no conflict of interest.

\section{References}

1. Zangeneh, H.; Zinatizadeh, A.A.L.; Habibi, M.; Akia, M.; Isa, M.H. Photocatalytic oxidation of organic dyes and pollutants in wastewater using different modified titanium dioxides: A comparative. J. Ind. Eng. Chem. 2015, 26, 1-36. [CrossRef]

2. Zhao, J.; Wang, A.; Li, X.; Wang, X. Removal of organic pollutants from reverse osmosis concentrate by electro-fenton process. Adv. Mater. Res. 2014, 2294, 955-959. [CrossRef]

3. Valero, E.; González-Sánchez, M.-I.; Pérez-Prior, M.-T. Removal of Organic Pollutants from Industrial Wastewater by Treatment with Oxidoreductase Enzymes. In The Handbook of Environmental Chemistry; Springer International Publishing: Berlin, Germany, 2014; pp. 317-339.

4. Pouran, S.R.; Abdul, A.A.R.; Ashri, W.M.; Daud, W. Review on the main advances in photo-Fenton oxidation system for recalcitrant wastewaters. J. Ind. Eng. Chem. 2015, 21, 53-69. [CrossRef]

5. Gabal, M.A.; Al-Harthy, E.A.; Angari, Y.M.; Abdel, S.M. MWCNTs decorated with $\mathrm{Mn}_{0.8} \mathrm{Zn}_{0.2} \mathrm{Fe}_{2} \mathrm{O}_{4}$ nanoparticles for removal of crystal-violet dye from aqueous solutions. Chem. Eng. J. 2014, 255, 156-164. [CrossRef]

6. Abdel, S.M.; El-Shishtawy, R.M.; Obaid, A.Y. Synthesis of magnetic multi-walled carbon nanotubes/magnetite/chitin magnetic nanocomposite for the removal of Rose Bengal from real and model solution. J. Ind. Eng. Chem. 2014, 20, 3559-3567.

7. Ahmed, M.J. Adsorption of non-steroidal anti-inflammatory drugs from aqueous solution using activated carbons. J. Environ. Manag. 2017, 190, 274-282. [CrossRef] [PubMed]

8. Fu, H.; Li, X.; Wang, J.; Lin, P.; Chen, C.; Zhang, X.; Suffet, I.H. Activated carbon adsorption of quinolone antibiotics in water: Performance, mechanism, and modeling. J. Environ. Sci. 2017, 56, 145-152. [CrossRef] [PubMed]

9. Kumar, A.; Jena, H.M. Adsorption of $\mathrm{Cr}(\mathrm{VI})$ from aqueous solution by prepared high surface area activated carbon from Fox nutshell by chemical activation with $\mathrm{H}_{3} \mathrm{PO}_{4}$. J. Environ. Chem. Eng. 2017, 5, 2032-2041. [CrossRef]

10. Demiral, H.; Güngör, C. Adsorption of copper (II) from aqueous solutions on activated carbon prepared from grape bagasse. J. Clean. Prod. 2016, 124, 103-113. [CrossRef]

11. Tajbakhsh, M.; Bazzar, M.; Ramzanian, S.F.; Tajbakhsh, M. Sulfonated nanoclay minerals as a recyclable eco-friendly catalyst for the synthesis of quinoxaline derivatives in green media. Appl. Clay Sci. 2014, 88, 178-185. [CrossRef]

12. Gómez, L.; Hueso, J.L.; Ortega-Liébana, M.C.; Santamaría, J.; Cronin, S.B. Evaluation of gold-decorated halloysite nanotubes as plasmonicphotocatalysts. Catal. Commun. 2014, 56, 115-118. [CrossRef]

13. Liu, S.-P. Flame retardant and mechanical properties of polyethylene/magnesium hydroxide/montmorillonite nanocomposites. J. Ind. Eng. Chem. 2014, 20, 2401-2408. [CrossRef]

14. Liu, M.; Jia, Z.; Jia, D.; Zhou, C. Recent advance in research on halloysite nanotubespolymer nanocomposite. Prog. Polym. Sci. 2014, 39, 1498-1525. [CrossRef]

15. Singh, P.; Ghosh, A.K. Torsional, tensile and structural properties of acrylonitrile-butadiene-styrene clay nanocomposites. Mater. Des. 2014, 55, 137-145. [CrossRef]

16. Maryan, A.S.; Montazer, M. Natural and organo-montmorillonite as antibacterial nanoclays for cotton garment. J. Ind. Eng. Chem. 2015, 22, 164-170. [CrossRef]

17. Atta, A.M.; Al-Lohedan, H.A.; ALOthman, Z.A.; Abdel-Khalek, A.A.; Tawfeek, A.M. Characterization of reactive amphiphilic montmorillonite nanogels and its application for removal of toxic cationic dye and heavy metals water pollutants. J. Ind. Eng. Chem. 2015, 31, 374-384. [CrossRef]

18. Liu, P.; Jiang, L.; Zhu, L.; Guo, J.; Wang, A. Synthesis of covalently crosslinked attapulgite/poly(acrylic acid-co-acrylamide) nanocomposite hydrogels and their evaluation as adsorbent for heavy metal ions. J. Ind. Eng. Chem. 2015, 23, 188-193. [CrossRef] 
19. Maris, S.; Meira, M.; IzéJardim, A.; Brandelli, A. Adsorption of nisin and pediocin on nanoclays. Food Chem. 2015, 188, 161-169.

20. Shirzad-Siboni, M.; Khataee, A.; Hassani, A.; Karaca, S. Preparation, characterization and application of a CTAB-modified nanoclay for the adsorption of an herbicide from aqueous solutions: Kinetic and equilibrium studies. C. R. Chim. 2015, 18, 204-214. [CrossRef]

21. Golubeva, O.Y.; Pavlova, S.V.; Yakovlev, A.V. Adsorption and in vitro release of vitamin B1 by synthetic nanoclays with montmorillonite structure. Appl. Clay Sci. 2015, 112, 10-16. [CrossRef]

22. Rasouli, F.; Aber, S.; Salari, D.; Khataee, A.R. Optimized removal of reactive Navy Blue SP-BR by organo-montmorillonite based adsorbents through central composite design. Appl. Clay Sci. 2014, 87, 228-234. [CrossRef]

23. Loginov, M.; Lebovka, N.; Vorobiev, E. Hybrid multiwalled carbon nanotube-Laponite sorbent for removal of methylene blue from aqueous solutions. J. Colloid Interface Sci. 2014, 431, 241-249. [CrossRef] [PubMed]

24. Wang, Q.; Zhang, J.; Zheng, Y.; Wang, A. Adsorption and release of ofloxacin from acid- and heat-treated halloysite. Colloid Surf. B 2014, 113, 51-58. [CrossRef] [PubMed]

25. Zhao, Y.; Abdullayev, E.; Vasiliev, A.; Lvov, Y. Halloysitenanotubule clay for efficient water purification. J. Colloid Interface Sci. 2013, 406, 121-129. [CrossRef] [PubMed]

26. Hassani, A.; Darvishi, R.; Soltani, C.; Karaca, S.; Khataee, A. Preparation of montmorillonite-alginate nanobiocomposite for adsorption of a textile dye in aqueous phase: Isotherm, kinetic and experimental design approaches. J. Ind. Eng. Chem. 2015, 21, 1197-1207. [CrossRef]

27. Guerra, D.L.; Pinto, A.A.J.; Souza, A.; Airoldi, C.; Viana, R.R. Kinetic and thermodynamic uranyl (II) adsorption process into modified Na-Magadiite and Na-Kanemite. J. Hazard. Mater. 2009, 166, 1550-1555. [CrossRef] [PubMed]

28. Guerraa, D.L.; Pintoa, A.A.; Airoldia, C.; Vianab, R.R. Rapid Communication Adsorption of arsenic (III) into modified lamellar Na-magadiite in aqueous medium thermodynamic of adsorption process. J. Solid State Chem. 2008, 181, 3374-3379. [CrossRef]

29. Royer, B.; Cardoso, N.F.; Lima, E.C.; Macedo, T.R.; Airoldi, C. Sodic and acidic crystalline lamellar magadiite adsorbents for the removal of methylene blue from aqueous solutions: Kinetic and equilibrium studies. Sep. Sci. Technol. 2010, 45, 129-141. [CrossRef]

30. E-Blaison, C.; Sauzeat, E.; Pelletier, M.; Michot, L.J.; Villieras, F.; Humbert, B. Hydration mechanisms and swelling behavior of Na-magadiite. Chem. Mater. 2001, 13, 1480-1486. [CrossRef]

31. Sault, A.G.; Martino, A.; Kawola, J.S.; Boespflug, E. Novel Sol-Gel-Based Pt Nanocluster catalysts for propane dehydrogenation. J. Catal. 2000, 191, 474-479. [CrossRef]

32. Fukuoka, A.; Higashimoto, N.; Sakamoto, Y.; Sasaki, M.; Sugimoto, N.; Inagaki, S.; Fukushima, Y.; Ichikawa, M. Ship-in-bottle synthesis and catalytic performances of platinum carbonyl clusters, nanowires, and nanoparticles in micro- and mesoporous materials. Catal. Today 2001, 66, 23-31. [CrossRef]

33. Aramendia, M.A.; Borau, V.; Jimenez, C.; Marinas, J.M.; Romero, F.J. Supramolecular templated synthesis of platinum-supported silica. Chem. Commun. 1999, 10, 873-874. [CrossRef]

34. Eswaramoorthy, M.; Niwa, S.; Toba, M.; Shimada, H.; Raj, A.; Mizukami, F. The conversion of methane with silica-supported platinum catalysts: The effect of catalyst preparation method and platinum particle size. Catal. Lett. 2001, 71, 55-61. [CrossRef]

35. Schwieger, W.; Selvam, T.; Gravenhorst, O.; Pfander, N.; Schlogl, R.; Mabande, G.T.P. Intercalation of $\left[\mathrm{Pt}\left(\mathrm{NH}_{3}\right)_{4}\right]^{2+}$ ions into layered sodium silicate magadiite: A useful method to enhance their stabilisation in a highly dispersed state. J. Phys. Chem. Solids 2004, 65, 413-420. [CrossRef]

36. Paz, G.L.E.; Munsignatti, C.O.; Pastore, H.O. Novel catalyst with layered structure: Metal substituted magadiite. J. Mol. Catal. A Chem. 2016, 422, 43-50. [CrossRef]

37. Moura, A.O.; Prado, A.G.S. Effect of thermal dehydration and rehydration on Namagadiite structure. J. Colloid Interface Sci. 2009, 330, 392-398. [CrossRef] [PubMed]

38. Cullity, B.D.; Stock, S.R. Elements of X-ray Diffraction, 3rd ed.; Prentice-Hall: Upper Saddle River, NJ, USA, 2001; pp. 167-171. ISBN 0-201-61091-4.

39. Beneke, K.; Legaly, G. Kenyaite-synthesis and properties. Am. Mineral. 1983, 68, 818-826.

40. Sing, K.S.W.; Everett, D.H.; Haul, R.A.W.; Moscou, L.; Pieroti, R.A.; Rouquerol, J.; Siemieniewska, T. Reporting physisorption data for gas/solid systems with special reference to the determination of surface area and porosity. Pure Appl. Chem. 1985, 57, 603. [CrossRef] 
41. Thommes, M.; Kaneko, K.; Neimark, A.V.; Olivier, J.P.F.; Rodriguez-Reinoso, R.J.; Sing, K.S.W. Physisorption of gases, with special reference to the evaluation of surface area and pore size distribution (IUPAC Technical Report). Pure Appl. Chem. 2015, 87, 1051-1069. [CrossRef]

42. De Souza e Silva, J.M.; Paul, G.; Bendall, J.; Bisio, C.; Marchese, L.; Pastore, H.O. Novel insights on magadiite disaggregation: A multitechnique study on thermal stability. Phys. Chem. Chem. Phys. 2013, 28, 13434-13445. [CrossRef] [PubMed]

43. Kallel, F.; Chaari, F.; Bouaziz, F.; Bettaieb, F.; Ghorbel, R.; Chaabouni, S.E. Sorption and desorption characteristics for the removal of a toxic dye, methylene blue from aqueous solution by a low cost agricultural by-product. J. Mol. Liq. 2016, 219, 279-288. [CrossRef]

44. Homaeigohar, S.; Zillohu, A.U.; Abdelaziz, R.; Hedayati, M.K.; Elbahri, M. A novel nanohybrid nanofibrous adsorbent for water purification from dye pollutants. Materials 2016, 9, 848. [CrossRef]

45. Abdel Salam, M. Synthesis and characterization of novel manganese oxide nanocorals and their application for the removal of methylene blue from aqueous solution. Chem. Eng. J. 2015, 270, 50-57. [CrossRef]

46. Li, C.; Zhong, H.; Wang, S.; Xue, J.; Zhang, Z. Removal of basic dye (methylene blue) from aqueous solution using zeolite synthesized from electrolytic manganese residue. J. Ind. Eng. Chem. 2015, 23, 344-352. [CrossRef]

47. Ghaedi, M.; Nasab, A.G.; Khodadoust, S.; Sahraei, R.; Daneshfar, A. Characterization of zinc oxide nanorods loaded on activated carbon as cheap and efficient adsorbent for removal of methylene blue. J. Ind. Eng. Chem. 2105, 21, 986-993. [CrossRef]

48. Ghaedi, M.; Nasab, A.G.; Khodadoust, S.; Rajabi, M.; Azizian, S. Application of activated carbon as adsorbents for efficient removal of methylene blue: Kinetics and equilibrium study. J. Ind. Eng. Chem. 2014, 20, 2317-2324. [CrossRef]

49. Zhang, M.; Wang, R.; Xiang, T.; Zhao, W.-F.; Zhao, C.-S. Preparation, characterization and application of poly(sodium p-styrenesulfonate)/poly(methyl methacrylate) particles. J. Ind. Eng. Chem. 2016, 34, 415-421. [CrossRef]

50. Rehman, M.S.U.; Kim, I.; Han, J.I. Adsorption of methylene blue dye from aqueous solution by sugar extracted spent rice biomass. Carbohydr. Polym. 2012, 90, 1314-1322. [CrossRef] [PubMed]

51. Alzaydien, A.S. Adsorption of methylene blue from aqueous solution onto a low-cost natural Jordanian Tripoli. Am. J. Environ. Sci. 2009, 5, 1047-1058. [CrossRef]

52. Natarajan, T.S.; Bajaj, H.C.; Tayade, R.J. Preferential adsorption behavior of methylene blue dye onto surface hydroxyl group enriched $\mathrm{TiO}_{2}$ nanotube and its photocatalytic regeneration. J. Colloid Interface Sci. 2014, 433, 104-114. [CrossRef] [PubMed]

53. Gobi, K.; Mashitah, M.D.; Vadivelu, V.M. Adsorptive removal of methylene blue using novel adsorbent from palm oil mill effluent waste activated sludge: Equilibrium, thermodynamics and kinetic studies. Chem. Eng. J. 2011, 171, 1246-1252. [CrossRef]

(C) 2017 by the author. Licensee MDPI, Basel, Switzerland. This article is an open access article distributed under the terms and conditions of the Creative Commons Attribution (CC BY) license (http://creativecommons.org/licenses/by/4.0/). 